\title{
Racial Discrimination in the Sharing Economy: Evidence from a Field Experiment
}

\author{
By BeNJAMIN EDELMAN, MichaEL LUCA, AND DAN SVIRSKY*
}

In an experiment on Airbnb, we find that applications from guests with distinctively African-American names are 16\% less likely to be accepted relative to identical guests with distinctively White names. Discrimination occurs among landlords of all sizes, including small landlords sharing the property and larger landlords with multiple properties. It is most pronounced among hosts who have never had an African-American guest, suggesting only a subset of hosts discriminate. While rental markets have achieved significant reductions in discrimination in recent decades, our results suggest that Airbnb's current design choices facilitate discrimination and raise the possibility of erasing some of these civil rights gains.

\footnotetext{
* Edelman: Harvard Business School, Morgan 462, 25 Harvard Way, Boston MA 02163 (bedelman@hbs.edu). Luca: Harvard Business School, Baker Library 457, 10 Harvard Way, Boston MA 02163 (mluca@hbs.edu). Svirsy: Harvard Business School and Harvard University Department of Economics, Baker Library 420A, 25 Harvard Way, Boston MA 02163 (dsvirsky@hbs.edu). We thank Ian Ayres, Larry Katz, Kevin Lang, Sendhil Mullainathan, Devah Pager, and seminar participants at eBay, Harvard Law School, Hong Kong University of Science and Technology, Indiana University, New York University, Northwestern University, Stanford University, and University at Albany for valuable feedback. We thank Haruka Uchida for tireless research assistance.
}

Over the past fifty years, there have been considerable societal efforts to reduce the level of discrimination against African-Americans in the United States. In the context of housing and rental accommodations, antidiscrimination laws have sought to eliminate discrimination through regulation. While racial discrimination continues to exist in rental markets, it has improved in the last two decades (Yinger 1998, U.S. Dep’t of Housing and Urban Development, 2012; compare Zhao et al., 2005 to Ondrich et al., 1999).

Yet in recent years, markets have changed dramatically, with a growing share of transactions moving online. In the context of housing, Airbnb has created a new market for short-term rentals that did not previously exist, allowing small landlords to 
increasingly enter the market. Whereas antidiscrimination laws ban the landlord of a large apartment building from discriminating based on race, the prevailing view among legal scholars is that such laws likely do not reach many of the smaller landlords using Airbnb (Belzer \& Leong, forthcoming; Todisco, 2015).

In this paper, we investigate the existence and extent of racial discrimination on Airbnb, the canonical example of the sharing economy. Airbnb allows hosts to rent out houses, apartments, or rooms within an apartment. To facilitate these transactions, Airbnb promotes properties to prospective guests, facilitates communication, and handles payment and some aspects of customer service. Airbnb allows hosts to decide whether to accept or reject a guest after seeing his or her name and often a picture - a market design choice that may further enable discrimination.

To test for discrimination, we conduct a field experiment in which we inquire about the availability of roughly 6,400 listings on Airbnb across five cities. Specifically, we create guest accounts that differ by name but are otherwise identical. Drawing on the methodology of a labor market experiment by Bertrand and Mullainathan (2004), we select two sets of names-one distinctively African-American and the other distinctively White. ${ }^{1}$

We find widespread discrimination against guests with distinctively African-American names. African-American guests received a positive response roughly $42 \%$ of the time, compared to roughly $50 \%$ for White guests. ${ }^{2}$ This 8 percentage point (roughly 16\%) penalty for African-American guests is particularly noteworthy when compared to the discrimination-free setting of competing short-term accommodation platforms such as

1 We build on the large literature using audit studies to test for discrimination. Past research considers African-Americans and applicants with prison records in the labor market (Pager 2003), immigrants in the labor market (Oreopoulos 2011), Arabic jobseekers (Carlsson \& Rooth 2007), gender (Lahey 2008), long-term unemployment (Ghayad 2014), and going to a for-profit college (Deming et al. 2016), among many others.

2 Some caution is warranted here. We only observe a gap between distinctively white and distinctively African-American names, which differ not only by suggested ethnicity but also potentially by socioeconomic status (Fryer and Levitt, 2004). For ease of exposition, we describe our results in terms of differences among the "African-American guests" or the "white guests," or use the term "race gap," without also specifying that our results may better be described as a "race and socioeconomic status gap." Section 5 discusses this issue in more detail. 
Expedia. The penalty is consistent with the racial gap found in contexts ranging from labor markets to online lending to classified ads to taxicabs. ${ }^{3}$

Combining our experimental results with observational data from Airbnb's site, we investigate whether different types of hosts discriminate more, and whether discrimination is more common at certain types of properties based on price or local demographics. Our results are remarkably persistent. Both African-American and White hosts discriminate against African-American guests; both male and female hosts discriminate; both male and female African-American guests are discriminated against. Effects persist both for hosts that offer an entire property and for hosts who share the property with guests. Discrimination persists among experienced hosts, including those with multiple properties and those with many reviews. Discrimination persists and is of similar magnitude in high and low priced units, in diverse and homogeneous neighborhoods.

Because hosts' profile pages contain reviews (and pictures) from recent guests, we can cross-validate our experimental findings using observational data on whether the host has recently had an African-American guest. We find that discrimination is concentrated among hosts with no African-American guests in their review history. When we restrict our analysis to hosts who have had an African-American guest in the recent past, discrimination disappears - reinforcing the external validity of our main results, and suggesting that discrimination is concentrated among a subset of hosts.

To explore the cost to a host of discriminating, we check whether each listing is ultimately rented for the weekend we inquired about. Combining that information with the price of each listing, we estimate that a host incurs a cost of roughly $\$ 65-\$ 100$ in foregone revenue by rejecting an African-American guest.

Overall, our results suggest a cause for concern. While discrimination has shrunk in more regulated offline markets, it arises and persists in online markets. Government agencies at both the federal and state level have routinely conducted audit studies to test for racial discrimination since 1955 in offline markets. One might imagine implementing

3 Doleac \& Stein (2013) find a 62\% to 56\% gap in offer rates for online classified postings. Bertrand and Mullainathan (2004) find a $10 \%$ to $6 \%$ gap in callback rates for jobs. Pope \& Sydnor (2011) find a $9 \%$ to $6 \%$ gap in lending rates in an online lending market. Ayres et al. (2005) find a $20 \%$ to $13 \%$ gap in how often taxi drivers receive a tip. 
regular audits in online markets as well; indeed, online audits might be easier to run at scale due to improved data access and reduced implementation cost.

Our results also reflect the design choices that Airbnb and other online marketplaces use. It is not clear a priori how online markets will affect discrimination. To the extent that online markets can be more anonymous than in-person transactions, there may actually be less room for discrimination. For example, Ayres and Siegelman (1995) find that African-American car buyers pay a higher price than white car buyers at dealerships, whereas Morton et al. (2003) find no such racial difference in online purchases. Similarly, platforms such as Amazon, eBay, and Expedia offer little scope for discrimination, as sellers effectively pre-commit to accept all buyers regardless of race or ethnicity. However, these advantages are by no means guaranteed, and in fact they depend on design choices made by each online platform. In this situation, Airbnb's design choices enable widespread discrimination.

\section{About Airbnb}

Airbnb is a popular online marketplace for short-term rentals. Founded in 2008, the site gained traction quickly and, as of November 2015, it offers 2,000,000 listings worldwide. ${ }^{4}$ This is more than three times as many as Marriott's 535,000 rooms worldwide. Airbnb reports serving over 40 million guests in more than 190 countries.

While the traditional hotel industry is dominated by hotels and inns that each offer many rooms, Airbnb enables anyone to post even a single room that is vacant only occasionally. Hosts provide a wealth of information about each listing, including the type of property (house, apartment, boat, or even castle, of which there are over 1400 listed), the number of bedrooms and bathrooms, the price, and location. Each host also posts information about herself. An interested guest can see a host's profile picture as well as reviews from past guests. Airbnb encourages prospective guests to confirm availability by clicking a listing's "Contact" button to write to the host. ${ }^{5}$ In our field experiments

4 https://www.airbnb.com/about/about-us

5 See “How do I know if a listing is available”, https://www.airbnb.com/help/question/137. 
(described in the next section), we use that method to evaluate a host's receptiveness to a booking from a given guest.

\section{Experimental Design}

\section{A. Sample and data collection}

We collected data on all properties offered on Airbnb in Baltimore, Dallas, Los Angeles, St. Louis, and Washington, D.C. as of July 2015. Our goal was to collect data from the top twenty metropolitan areas from the 2010 census. We started with these five cities because they had varying levels of Airbnb usage and came from diverse geographic regions. Baltimore, Dallas, and St. Louis offer several hundred listings each, while Los Angeles and Washington, D.C. have several thousand. We stopped data collection after these five cities because Airbnb became increasingly rapid in blocking our automated tools which logged into guest accounts and communicated with hosts. (We considered taking steps to conceal our methods from Airbnb, but ultimately declined to do so.)

Because some hosts offer multiple listings, we selected only one listing per host using a random number generator. This helped to reduce the burden on any given host, and it also prevented a single host from receiving multiple identical emails. Each host was contacted for no more than one transaction in our experiment.

We also collected data from each host's profile page. This allowed us to analyze host characteristics in exceptional detail. First, we saved the host's profile image. We then employed Mechanical Turk workers to assess each host image for race (White, AfricanAmerican, Asian, Hispanic, multiracial, unknown), gender (male, female, two people of the same gender, two people of different genders, unknown), and age (young, middleaged, old). We hired two Mechanical Turk workers to assess each image, and if the workers disagreed on race or gender, we hired a third to settle the dispute. If all three workers disagreed (as happened, for example, for a host whose profile picture was an image of a sea turtle), we manually coded the picture. We coded race as "unknown" when the picture did not show a person. Through this procedure, we roughly categorized hosts by race, gender, and age.

Profile pages also revealed other variables of interest. We noted the number of properties each host offers on Airbnb, anticipating that professional hosts with multiple 
properties might discriminate less often than others. We retrieved the number of reviews the host has received, a rough measure of whether the host is an avid Airbnb user or a casual one. We further checked the guests who had previously reviewed each host. Airbnb posts the photo of each such guest, so we used Face++, a face-detection API, to categorize past guests by race, gender, and age. ${ }^{6}$ This allows us to examine relationships between a host's prior experience with African-American guests and the host's rejection of new African-American requests.

We also collected information about each listing. We recorded the price of the listing, the number of bedrooms and bathrooms, the cancelation policy, any cleaning fee, and the listing's ratings from past guests. We also measured whether the listing offered an entire unit versus a room in a larger unit, yielding a proxy for how much the host interacts with the guest.

Each listing included a longitude and latitude, which allowed us to link to census demographic data to assess the relationship between neighborhood demographics and discrimination. After linking the latitude and longitude to a census tract, we used census data on the number of African-American, Hispanic, Asian, and White individuals. Table 1 presents summary statistics about the hosts and listings as well as balanced treatment tests.

\section{[ Insert Table 1 Here ]}

We later checked each listing to see whether hosts were ultimately able to fill openings. Our guests inquired about reservations eight weeks in advance. Thus, if a guest sent a message on August 1 about the weekend of September 25, we checked on Friday, September 24 to see whether the specified listing was still listed as available.

6 In addition to detecting race, gender, and age, Face++ estimates its confidence for each trait. When Face++ was unable to make a match or its confidence was below 95 out of 100, we used Mechanical Turk, to categorize the past guest via the method described above. 


\section{B. Treatment groups}

Our analysis used four main treatment groups based on the perceived race and gender of the test guest accounts. Hosts were contacted by guests with names that signaled African-American males, African-American females, White males, and White females, drawn from Bertrand and Mullainathan (2004). The list was based on the frequency of names from birth certificates of babies born between 1974 and 1979 in Massachusetts. Distinctively White names are those that are most likely to be White, conditional on the name, and similarly for distinctively African-American names. To validate the list, we conducted a survey in which we asked participants to quickly categorize each name as White or African-American. With just three seconds permitted for a response, survey takers had little time to think beyond a gut response. The survey results, presented in Appendix Table 1, confirm that the names continue to signal race. ${ }^{7}$

We then created twenty Airbnb accounts, identical in all respects except for guest names. Our names included ten that are distinctively African-American and ten distinctively White names, divided into five male and five female names within each group. To avoid the confounds that would result from pictures, we use only names; our Airbnb profiles include no picture of the putative guest. From these twenty guest accounts, we sent messages to prospective hosts. Each host was randomly assigned one of our twenty guest accounts. Figure 1 presents a representative email from one of our guests to an Airbnb host. The name and dates changed depending on the message sender and when the message was sent. ${ }^{8}$ In choosing the dates, we asked hosts about a weekend that was approximately eight weeks distant from when the message was sent. We limited our search to those properties that were listed as available during the weekend in question.

\section{[ Insert Figure 1 Here ]}

\footnotetext{
7 On a scale of 0 to 1 , where 0 is African-American, the White female names each had an average survey response of 0.90 or above, and the African-American female names all had an average score of 0.10 or below. The male names showed slightly more variation but tell the same story: all the White male names scored 0.88 or above, and all the African-American male names except for Jermaine Jones scored 0.10 or below. The Appendix presents the full results of the survey.

8 No more than 48 hours elapsed between our first contact to a host in a given city, and the completion of our contacting hosts in that city. Furthermore, no hosts in our sample had listings in more than one of the five cities we tested. Hence, it is unlikely that a host contacted later on in the study would have learned about the experiment.
} 


\section{Experimental procedure}

We sent roughly 6,400 messages to hosts between July 7, 2015 and July 30, 2015. ${ }^{9}$ Each message inquired about availability during a specific weekend in September. When a host replied to a guest, we replied to the host with a personal message clarifying that we (as the guest) were still not sure if we would visit the city or if we would need a place to stay. We sent this reply in order to reduce the likelihood of a host holding inventory for one of our hypothetical guests.

We tracked host responses over the 30 days that followed each request. A research assistant then coded each response into categories. The majority of responses were in one of six groups: "No response” (if the host did not respond within 30 days); "No or listing is unavailable"; "Yes"; "Request for more information" (if the host responded with questions for the guest); "Yes, with questions" (if the host approved the stay but also asked questions); “Check back later for definitive answer”; and "I will get back to you." As these categories show, our initial categorizations used subtle distinctions between possible responses. In our analyses below, however, we restrict our attention to the simplest response - "Yes" - though all of our results are robust to using "No" instead, as well as to ignoring non-responses or to using broader definitions of "Yes."

We collected all data using scrapers we built for this purpose. We sent inquiries to Airbnb hosts using web browser automation tools we built for this purpose. Our Institutional Review Board approved our methods before we began collecting data.

\section{Results}

Table 2 presents the main effect. We find that inquiries from guests with Whitesounding names are accepted roughly $50 \%$ of the time. In contrast, guests with AfricanAmerican-sounding names are accepted roughly 42\% of the time. Columns 2 and 3 introduce additional control variables related to the host or the property. The effect stays

9 Our initial goal was to collect roughly 10,000 responses. This was based on a power analysis, which in turn used an effect size calculated from Edelman and Luca (2014). To find a similar effect size, we would need a sample size of roughly 3,000 hosts. But, to calculate an effect among a subgroup of hosts, like African-American hosts, which represent roughly $7 \%$ of the Airbnb population, we would need a sample size closer to 10,000 . We fell short of this goal for an exogenous reason: Airbnb shut down the experimental accounts after we collected roughly 6,400 responses. 
constant at a roughly eight percentage point gap across these specifications, controlling for the host's gender, race, an indicator for whether the host has multiple listings, an indicator for whether the property is shared, host experience (whether the host has more than ten reviews), and the log of the listing price.

\section{[ Insert Table 2 Here ]}

As noted, we break down hosts' responses into 11 categories. Figure 2 shows the frequency of each response by race. One might worry that results are driven by differences in host responses that are hard to classify, such as conditional "Yes" responses. Similarly, we would be concerned if our findings were driven by differences in response rate. African-American accounts might be more likely to be categorized as spam, or hosts may believe that African-American accounts are more likely to be fake, in which case one might expect higher non-response rates for African-American accounts. But as Figure 2 shows, the discrimination results occur because of differences in simple "Yes" or "No" responses, not because of non-responses or intermediate responses (like a conditional "Yes”).

\section{[ Insert Figure 2 Here ]}

In the rest of this section, we use the wealth of data available on Airbnb about the host and location for each listing to look for factors that influence the gap between white and African-American names. Does the identity of the host matter? Does the location of the property matter? Generally, we find that the discrimination is remarkably robust.

\section{A. Effects by host characteristics}

We first check whether our finding changes based on the identity of the host. If discrimination is driven by homophily (in-group bias), then the host's race should matter. According to this theory, hosts might simply prefer guests of the same race. If homophily were the primary factor driving differential guest acceptance rates, then AfricanAmerican guests would face higher acceptance rates from African-American hosts. Table 3 presents regressions that include guest race, host race, and an interaction term. Across 
the entire sample of hosts, the interaction between the race and guest of the host is not significantly different from zero, but the point estimate is noisy. This result masks heterogeneity across genders. Columns 2 and 3 of Table 3 report the same regression limited to male hosts and female hosts, respectively. Among male hosts, the interaction between the host's race and guest's race shows a widening of the race gap by 11 percentage points, whereas among females, the race gap narrows by 11 percentage points. Both estimates are noisy; we cannot reject coefficients of zero. ${ }^{10}$

[ Insert Table 3 Here ]

[ Insert Table 4 Here ]

Discrimination may also be influenced by a host's proximity to the guest. For example, Becker (1957) formalizes racial discrimination as distaste for interactions with individuals of a certain race. On Airbnb, a host must classify each listing as offering an entire unit, a room within a unit, or a shared room. We classify anything other than an entire unit as a "shared property." Column 1 of Table 5 shows that the race gap is roughly the same whether or not a property is shared. (In unreported results, we find that the race gap stays roughly the same in shared properties with only one bathroom.)

One might expect a distinction between casual Airbnb hosts who occasionally rent out their homes, versus professional hosts who offer multiple properties. Roughly a sixth of Airbnb hosts manage multiple properties, and roughly $40 \%$ of hosts have at least 10 reviews from past guests. Columns 2 and 3 explore the extent of discrimination among hosts with multiple locations, and those with more than 10 reviews. Across these specifications, the race gap persists with roughly the same magnitude. ${ }^{11}$

10 Table 4 explores the effect of the host's race with more nuance. It shows the proportion of Yes responses from each gender/race cell among hosts in response to each gender/race cell among guests. African-American male hosts discriminate against AfricanAmerican male and female guests. White hosts of both genders are more likely to accept white guests of either gender. AfricanAmerican female hosts are the only exception: they accept African-American female guests more than any other group. Thus, with the exception of African-American females, the data is inconsistent with homophily. Table 4 focuses on race/gender subgroups, but we present a more systematic breakdown of the raw results in Appendix Table 2. We ultimately focused on race/gender cells for ease of presentation.

11 Hosts with at least 10 reviews still have a race gap, but the acceptance rates for both races are higher among these hosts. Instead of the $50 \%$ to $42 \%$ gap we see among all hosts, the race gap among hosts with at least 10 reviews, or hosts with multiple properties, is closer to $60 \%$ to $52 \%$. Hence, the racial gap is the same in terms of percentage points, but not in terms of percent. The same is true in a later specification, where we look at the race gap among hosts with at least one review from an African-American guest. In all these 
To the extent that discrimination rates are changing over time, one might expect discrimination to be less common among younger hosts. To assess this possibility, we employed Mechanical Turk workers to categorize hosts as young, middle-aged, or old. Column 4 shows that discrimination also persists across the age categories with roughly the same magnitude.

\section{[ Insert Table 5 Here ]}

\section{B. Effects by listing characteristics}

Just as discrimination was robust across host characteristics, we find that discrimination does not vary based on the cost or location of the property. Column 1 of Table 6 shows that, overall, listings above the median price are more likely to reject inquiries. However, discrimination remains both among more expensive and less expensive listings.

We can also check whether the listing was eventually filled (for the nights in question) to create a proxy for the desirability of the listing. First, we fit a Probit model to predict the likelihood that the listing was filled, controlling for a fixed city effect and a host of covariates. $^{12}$ Then we assign each listing a probability of being filled. This lets us test whether discrimination changes based on the listing's desirability. ${ }^{13}$ It does not.

We also hypothesized that the extent of discrimination might vary with the diversity of a neighborhood. More generally, one might expect that geography matters and that discrimination is worse in some areas than others, due to market structure or underlying rates of discrimination among a population. Merging data on neighborhoods by census tract, Column 2 shows that the extent of discrimination does not vary with the proportion of nearby residents who are African-American. Column 3 shows that discrimination is ubiquitous: it does not vary with the number of Airbnb listings within the census tract. We also find discrimination in all cities in our sample, as shown in Appendix Table 3.

specifications, the change in the odds ratio is not economically significant. We have insufficient statistical power to reject the possibility that the odds ratios remain constant while the gap changes slightly.

12 The covariates are as follows: the host's race and gender, the price, number of bedrooms, whether the property is shared, whether the bathroom is shared, the number of reviews, the age of the host, whether the host operates multiple listings, the proportion of White people in the census tract, and the number of Airbnb listings in the census tract.

13 We thank an anonymous reviewer for suggesting this approach. 


\section{[ Insert Table 6 Here ]}

\section{Robustness - effects by name}

Table 7 shows the proportion of positive responses broken down by name. The effect is robust across choice of names. For example, the African-American female name with the most positive responses (Tamika) received fewer positive responses than the White female name with the fewest positive responses (Kristen), though this difference is not statistically significant. Similarly, the African-American males with the most positive responses (Darnell and Rasheed) received fewer acceptances than the White male with the fewest positive responses (Brad).

\section{[ Insert Table 7 Here ]}

\section{Comparing experimental results with observational patterns}

Each listing page includes reviews from previous guests, along with profile pictures for these guests. This allows us to see which hosts previously accepted African-American guests (although not all guests leave reviews and not all guests have photos that reveal their race). We use this data to assess the external validity of our results.

We collected profile pictures from the ten most recent reviews on each listing page. We categorized these past guests by race and gender, finding that $29 \%$ of hosts in our sample had at least one review from an African-American guest. We then regressed the likelihood of a host responding positively to our inquiry on the race of the guest, whether the host has at least one recent review from an African-American guest, and an interaction between these variables. Column 5 of Table 5 reports the results. We find that the race gap drops sharply among hosts with at least one recent review from an AfricanAmerican guest. We cannot reject zero difference for requests from our African- 
American test accounts versus requests from our White test accounts, though this result is only significant at the $10 \%$ level. $^{14}$

This finding reinforces our interpretation of our main effects, including the role of race and the interpretation that observed differences reflect racial discrimination by Airbnb hosts. Put another way, if our findings are driven by a quirk of our experimental design, rather than race, then it is difficult to explain why the race gap disappears precisely among hosts with a history of accepting African-American guests.

\section{E. Importance of profile pictures and more complete profiles}

A related concern is that we used guest profiles that were relatively bare. A host may hesitate to accept a guest without a profile picture or past reviews. Of course, this alone cannot explain the race gap, since both white and African-American guests had bare profiles. But it does raise the question of whether more complete profiles could mitigate discrimination. ${ }^{15}$

Internal data from Airbnb and observational data on Airbnb users both suggest that profile pictures alone are unlikely to make much difference. With access to internal Airbnb data, Fradkin (2015) looks at roughly 17,000 requests sent to hosts and finds that guests are rejected $49 \%$ of the time. Notably, these requests from ordinary Airbnb users, with typical Airbnb profiles, were rejected at a rate similar to that of our guests. In our experiment, as detailed in Appendix Table 4, 44\% of guests were rejected or received no response. Another $11 \%$ received a message from a host requesting more information. The remaining $46 \%$ were accepted. The similarity in rejection rates suggests that incompleteness of our guests' profiles is not likely to be causing a change in the rejection rate, and reinforces the ecological validity of our experimental design.

14 These findings are robust to alternative specifications of a host's past guests. The same substantive results hold if we look at the raw number of reviews from African-Americans, rather than whether there is at least one such review. The same is true if we use the proportion of reviews from African-American guests.

15 Similarly, our experiment does not assess whether discrimination occurs because of race or social class. Hanson \& Hawley (2011) find, in a field experiment on Craigslist's housing market using similar methodology, that renters with African-American names face a penalty, but that the penalty decreases if the email sent to a landlord signals higher social class. Under some specifications, African-Americans face a statistically significant penalty based on race and an additional penalty for signaling low class, also statistically significant. Under other specifications, the racial gap is not statistically significant when comparing white and African-American guests who both signal high social class. On the whole, the paper indicates that social class and race both play a role. 
Other methods indicate that profile pictures seem to have little impact on acceptance decisions. In a logistic regression estimating the probability of receiving a rejection from a host, again using internal Airbnb data, Fradkin (2015) finds that including a profile picture has no significant effect. This matches the observational data we collect: in a random selection of Airbnb users, we found that only $44 \%$ have a profile picture. The proportion of guests with a profile picture is higher among users who have left a review, but nonetheless both analyses indicate that the existence of profile pictures plays a small role in host decision-making. Further, even if profile pictures impact rejection rates, it is not clear that the impact should be differential by race. For example, one might expect that pictures would make a guest's race more salient. If our results are driven by race, then our findings would be a lower bound on the true effect.

One limitation of our experiment is that we do not observe the effect of past reviews on discrimination. If our findings are driven by statistical discrimination, positive reviews from previous hosts may reduce the extent of discrimination. However, three factors suggest that reviews are an incomplete response to a discrimination problem. First, our acceptance rates are similar to overall acceptance rates on Airbnb (Fradkin 2015), which indicates that hosts are not treating our test guest accounts differently for lack of reviews, meaning that reviews would be unlikely to eliminate discrimination. Indeed, for reviews to eliminate discrimination, they would need to provide a 16 percent differential increase in acceptance rates for African-Americans, relative to White guests. Second, all Airbnb users necessarily start without past reviews, so a review system would not address any initial barriers to entry that guests face. Third, a subjective review system can itself allow or facilitate discrimination. (See, e.g., Goldin and Rouse, 2000, finding that visually confirming a musician's gender may influence an expert's judgment of her work.) Whatever mechanism is causing a lower acceptance rate for the African-American guests may also cause a worse rating.

\section{F. How much does discrimination cost hosts?}

A host incurs a cost for discriminating when rejecting a guest causes a unit to remain empty. The expected cost depends on the likelihood of the property remaining vacant, which in turn depends on the thickness of the market. If a host can easily find a 
replacement guest, then discrimination is nearly costless for the host. But if a property remains vacant after the host rejects a guest, then discrimination imposes a more significant cost. In other words, the impact on net revenue from discriminating depends on the likelihood of filling a unit with someone of the host's preferred race after rejecting a guest of a disfavored race.

Because we collect data about each property's availability after a host declines a guest, we can estimate the cost in net revenue from discrimination. Suppose a host charges price $p$ for a listing and pays listing fees $f$ to Airbnb. Let $\pi_{\text {replace }}$ be the probability of filling the property after rejecting a guest in our study. Then the cost in net revenue of discrimination is as follows:

$$
\Delta \text { Net Revenue }=(p-f)-\pi_{\text {replace }} \cdot(p-f)=\left(1-\pi_{\text {replace }}\right) \cdot(p-f)
$$

That is, the cost of discrimination, in terms of net revenue, is the revenue that the host forgoes if the listing remains empty multiplied by the probability that the listing remains empty.

In our data, hosts who rejected or never responded to our inquiries had properties with a median price of $\$ 163$ and a mean price of $\$ 295 .{ }^{16}$ The numbers are similar and slightly higher if we restrict the sample further to those hosts who rejected African-American guests, or if we expand the sample to hosts who responded positively Yes to our accounts. ${ }^{17}$ Airbnb charges each host a fee equal to $3 \%$ of the listing price.

After our inquiries, roughly $25.9 \%$ of the listings in our study remained vacant on the dates we requested after rejecting or not responding to one of our guests. Another $37.9 \%$ remained listed but were no longer available on those dates, suggesting that the host either found another guest or decided to no longer make the property available on the specified dates. The remaining $36.1 \%$ of properties were no longer listed on Airbnb.

16 In calculating price, we sum the listing price and any cleaning fee.

17 An anonymous reviewer correctly points out that the host we are interested in is the host on the margin of discriminating. But there are hosts far from this margin both within the group of hosts who said Yes and within the group of hosts who said No. Nonetheless, our calculations in this section are not sensitive to which group of hosts we include. When including hosts who said Yes, the median price drops from $\$ 163$ to $\$ 150$, and the probability of finding a replacement guest rises to $64 \%$ instead of $59.4 \%$ (excluding disappearing hosts) or $45 \%$ instead of $37.9 \%$ (including disappearing hosts). Thus, the cost of discrimination drops by about $\$ 10$ or $\$ 20$ among hosts who say Yes, and therefore either did not discriminate against the African-American accounts or did not get a chance to do so. 
Because it is unclear whether the hosts who exit should be excluded from the sample or treated as not having found a replacement, we develop two estimates.

If we exclude these disappearing hosts from our calculation, 59.4\% of hosts found a replacement guest. Setting $p$ equal to the median price (\$163) and fees at 3\% of the median price:

$$
\Delta \text { Net Revenue }=(1-.594) \cdot(\$ 163-.03 \cdot \$ 163) \approx \$ 64.19
$$

If we treat disappearing listings as vacancies, in effect assuming that the host of a dropped listing was not able to find a replacement guest, then only $37.9 \%$ of hosts found a replacement guest. The cost of discrimination rises as a result:

$$
\Delta \text { Net Revenue }=(1-.379) \cdot(\$ 163-.03 \cdot \$ 163) \approx \$ 98.19
$$

In this analysis, we focus on the net revenue, which does not incorporate the marginal cost of each night the listing is rented, since we do not directly observe costs. The cost of hosting includes various types of host effort or wear-and-tear to the property. In principle, hosting also entails a risk of damage by a guest, though throughout the relevant period Airbnb automatically provided all hosts with property insurance, which reduces the risk. Our calculation also excludes unobserved benefits of hosting, such as the possibility that a positive review draws more guests in the future and improves the listing position on Airbnb. A full estimate of profit would also need to consider the time cost of looking for new guests after rejecting someone on the basis of race. ${ }^{18}$

While these estimates are clearly noisy, they suggest that hosts incur a real cost by discriminating. The median host who rejects a guest because of race is turning down between $\$ 65$ and $\$ 100$ of revenue.

18 Our calculation also ignores other factors that cut in both directions. Responding with a Yes to a guest does not provide $100 \%$ certainty of a paid booking; the guest may choose another option or may not make the trip. In that case, our estimates overstate the revenue loss. Similarly, we have imperfect information about whether a host found a replacement guest. Among other complexities, our guests requested two-night stays; we treat a host as having filled a listing if the host found a replacement guest for at least one of the nights, though a host who filled only one of the nights has nonetheless lost one night of revenue. 


\section{Discussion}

Online platforms such as Airbnb create new markets by eliminating search frictions, building trust, and facilitating transactions (Lewis 2011, Luca forthcoming). With the rise of the sharing economy, however, comes a level of discrimination that is impossible in the online hotel reservations process. Clearly, the manager of a Holiday Inn cannot examine names of potential guests and reject them based on race or socioeconomic status or some combination of the two. Yet, this is commonplace on Airbnb, which now accounts for a growing share of the short-term rental market.

Our results contribute to a small but growing body of literature suggesting that discrimination persists — and we argue may even be exacerbated - in online platforms. Edelman and Luca (2014) show that African-American hosts on Airbnb seek and receive lower prices than White hosts, controlling for the observable attributes of each listing. Pope and Sydnor (2011) find that loan listings with pictures of African-Americans on Prosper.com are less likely to be funded than similar listings with pictures of White borrowers. Doleac and Stein (2013) show that buyers are less likely to respond to Craigslist listings showing an iPod held by a Black hand compared to an identical ad with a White hand. In contrast, Morton et al. (2003) find no difference by race in price paid for cars in online purchases - a sharp contrast to traditional channels (see, e.g., List, (2004); Zhao et al., (2005)).

One important limitation of our experiment is that we cannot identify the mechanism causing worse outcomes for guests with distinctively African-American names. Prior research shows that distinctively African-American names are correlated with lower socioeconomic status (Fryer and Levitt, 2004). Our findings cannot identify whether the discrimination is based on race, socioeconomic status, or a combination of these two. That said, we note that discrimination disappears among hosts who have previously accepted African-American guests. One might worry that discrimination against our test guest accounts results from our choice of names and hence does not represent patterns that affect genuine Airbnb guests. However, we find that discrimination is limited to hosts who have never had an African-American guest, which suggests that our results are consistent with any broader underlying patterns of discrimination. 
Similarly, our experiment does not provide a sharp test of alternative models of discrimination. The theoretical literature on discrimination often distinguishes between statistical and taste-based discrimination. While our experimental design cannot reject either mechanism, our findings suggest a more nuanced story than either of the classic models. For one, we find homophily among African-American females, but not among other race/gender combinations. Furthermore, we find that discrimination is not sensitive to a measure of proximity between the host and guest. Both findings are in tension with pure taste-based discrimination. But we also find some evidence against pure statistical discrimination. As noted above, we find that hosts who have had an African-American guest in the past exhibit less discrimination than other hosts. This suggests that, at the very least, hosts are using different statistical models as they evaluate potential guests.

\section{A. Designing a discrimination-free marketplace}

Because online platforms choose which information is available to parties during a transaction, they can prevent the transmission of information that is irrelevant or potentially pernicious. Our results highlight a platform's role in preventing discrimination or facilitating discrimination, as the case may be. If a platform aspires to provide a discrimination-free environment, its rules must be designed accordingly.

Airbnb has several options to reduce discrimination. For example, it could conceal guest names, just as it already prevents transmission of email addresses and phone numbers so that guests and hosts cannot circumvent Airbnb's platform and its fees. Communications on eBay's platform have long used pseudonyms and automatic salutations, so Airbnb could easily implement that approach.

Alternatively, Airbnb might further expand its “Instant Book” option, in which hosts accept guests without screening them first. Closer to traditional hotels and bed and breakfasts, this system would eliminate the opportunity for discrimination. This change also offers convenience benefits for guests, who can count on their booking being confirmed more quickly and with fewer steps. However, in our sample, only a small subset of hosts currently allow instant booking. Airbnb could push to expand the use of this feature, which would also serve the company's broader goal of reducing search frictions. 
More generally, our results suggest an important tradeoff for market designers, who set the rules of online platforms, including the pricing mechanisms (Einav et al 2013) and the information that is available and actionable at the time of transaction (Luca forthcoming). Market design principles have generally focused on increasing the information flow within a platform (Bolton et al 2013, Che and Horner 2014, Dai et al 2014, Fradkin et al 2014), but we highlight a situation in which platforms may be providing too much information.

\section{B. Policy Implications}

Because the legal system grants considerable protection to online marketplaces, Airbnb is unlikely to be held liable for allowing discrimination on its platform. Within the United States, the Civil Rights Act of 1964 prohibits discrimination in hotels (and other public accommodations) based on race, color, religion, or national origin. But these laws appear to be a poor fit for the informal sharing economy, where private citizens rent out a room in their home (Belzer and Leong, forthcoming; Todisco, 2015). As discussed in Edelman and Luca (2014), any changes by Airbnb would likely be driven by ethical considerations or public pressure rather than law. In contrast, offline rental markets and hotels have been subject to significant regulation (as well as audit studies to test for discrimination) for decades. This contributes to worry among policy-makers that online short-term rental markets like Airbnb may be displacing offline markets, which are more heavily regulated (Schatz et al, 2016). One clear policy implication is that regulators may want to audit Airbnb hosts using an approach based on our paper-much like longstanding efforts to reduce discrimination in offline rental markets.

One might have hoped that online markets would cure discrimination, and it seems a different design might indeed do so. Regrettably, our analysis indicates that at Airbnb, this is not yet the case.

\section{Invited Postscript: Airbnb Implements Market Design Changes}

Prior to this paper, Airbnb repeatedly ignored allegations of discrimination on the platform (Finley, 2016; Larson \& Harris, 2016). In response to our study and growing user complaints, the company put together a task force 
including former attorney general Eric Holder to propose a set of market design changes to reduce discrimination on the platform (Benner, 2016). On the same day this paper was accepted for publication in this journal, Airbnb announced the company's planned changes. Changes include a goal of increasing the proportion of hosts who offer Instant Book (letting guests book instantly, without the host first seeing the guest's picture or name), a reminder to all users of the company's anti-discrimination policy, increased training for Airbnb staff to assist users who report discrimination, and testing reduced prominent of guests' photos. However, as of the time of publication, Airbnb continued to reject suggestions to conceal guest photos and names before booking. 


\section{REFERENCES}

Ayres, I., \& Siegelman, P. (1995). Race and Gender Discrimination in Bargaining for a New Car. American Economic Review, 85(3), 304-321.

Ayres, I., F. Vars, \& N. Zakariya. (2005). To Insure Prejudice: Racial Disparities in Taxicab Tipping. Yale Law Journal, 114(7), 1613-1674.

Becker, G. (1957). The Economics of Discrimination. The University of Chicago Press.

Belzer, A., \& Leong, N. (2017). The New Public Accommodations. Georgetown Law Journal, 105 (forthcoming).

Benner, K. (2016). Airbnb Adopts Rules to Fight Discrimination by Its Hosts. New York Times, A1, available at http://www.nytimes.com/2016/09/09/technology/airbnb-antidiscrimination-rules.html.

Bertrand, M., \& Mullainathan, S. (2004). Are Emily and Greg More Employable Than Lakisha and Jamal? A field experiment on albor market discrimination. American Economic Review, 94(4), 991-1013.

Bolton, G., B. Greiner, and A. Ockenfels. (2013). Engineering Trust: Reciprocity in the Production of Reputation Information. Management Science, 59(2), 265-285.

Carlsson, M., \& Rooth, D. (2007). Evidence of Ethnic Discrimination in the Swedish Labor Market Using Experimental Data. Labour Economics, 14(4), 716-729.

Che, Y. and J. Hörner. (2014). Optimal Design for Social Learning. Working Paper.

Dai, W., G. Jin, J. Lee, \& M. Luca. (2014). Optimal Aggregation of Consumer Ratings: an Application to Yelp.com. NBER Working Paper.

Deming, D. J., Yuchtman, N., Abulafi, A., Golding, C., \& Katz, L. F. (2016). The Value of Postsecondary Credentials in the Labour Market: An Experimental Study. American Economic Review, 106(3), 778-806.

Doleac, J., \& L. Stein. (2013). The Visible Hand: Race and Online Market Outcomes. Economic Journal, 123(572), 469-492.

Edelman, B, and M. Luca. (2014). Digital Discrimination: The Case of Airbnb.com. Harvard Business School Working Paper.

Einav, L., C. Farronato, J. Levin, \& N. Sundaresan. (2013). Sales Mechanisms in Online Markets: What Happened to Internet Auctions? Working paper.

Finley, T. (2016). These Airbnb Alternatives Want To Make Travel More Welcoming 
For Black People. The Huffington Post. Available at http://www.huffingtonpost.com/entry/innclusive-noirbnb-airbnbalternatives_us_5768462ae4b0853f8bf1c675

Fradkin, A., E. Grewal, D. Holtz, and M. Pearson, (2014). Bias and Reciprocity in Online Reviews: Evidence from Field Experiments on Airbnb. Working Paper.

Fradkin, A, (2015). Search Frictions and the Design of Online Marketplaces. Working Paper.

Fryer, R., and S. Levitt. (2004). The Causes and Consequences of Distinctively Black Names. The Quarterly Journal of Economics, 119(3), 767-805.

Ghayad, R. (2014). The Jobless Trap. Working Paper.

Goldin, C., \& Rouse, C. (2000). Orchestrating Impartiality. American Economic Review, 90(4), 715-741.

Hanson, A., \& Hawley, Z. (2011). Do Landlords Discriminate in the Rental Housing Market? Evidence from an Internet Field Experiment in U.S. Cities. Journal of Urban Economics, 70(2-3), 99-114.

Lahey, J. N. (2008). Age, Women, and Hiring: An Experimental Study. Journal of Human Resources, 43(1), 30-56.Lewis, G. (2011). Asymmetric Information, Adverse Selection and Online Disclosure: The Case of eBay Motors. American Economic Review, 101(4): 1535-46.

Larson, E. \& Harris, A. (2016). Airbnb Sued, Accused of Ignoring Hosts' Race Discrimination. Bloomberg News. Available http://www.bloomberg.com/news/articles/2016-05-18/airbnb-sued-over-host-s-allegeddiscrimination-against-black-man

Lewis, G. (2011). Asymmetric Information, Adverse Selection and Online Disclosure: The Case of eBay Motors. American Economic Review, 101(4): 1535-46.

List, J.A. (2004). The Nature and Extent of Discrimination in the Marketplace: Evidence from the Field. The Quarterly Journal of Economics, 119(1): 49-89.

Luca, M. forthcoming. User-generated Content and Social Media. Handbook of Media Economics.

Morton, F., F. Zettelmeyer, and J. Silva-Risso. (2003). Consumer Information and Discrimination: Does the Internet Affect the Pricing of New Cars to Women and 
Minorities? Quantitative Marketing and Economics, 1(1), 65-92.

Ondrich, J., Stricker, A., and Yinger, J. (1999). Do Landlords Discriminate? The Incidence and Causes of Racial Discrimination in Rental Housing Markets. Journal of Housing Economics, 8, 185-204.

Oreopoulos, P. (2011). Why do skilled immigrants struggle in the labor market? A field experiment with thirteen thousand resumes. American Economic Journal: Economic Policy, 3(4), 148-171.

Pager, D. (2003). The Mark of a Criminal Record. American Journal of Sociology, 108(5), 937-975.

Pope, D. G., \& Sydnor, J. R. (2011). What's in a Picture?: Evidence of Discrimination from Prosper.com. Journal of Human Resources, 46(1), 53-92.

Schatz, B., Feinstein, D., \& Warren, E. (2016). Letter to the Edith Ramirez, Chairwoman of the Federal Trade Commission.

Todisco, M. (2015). Share and Share Alike? Considering Racial Discrimination in the Nascent Room-Sharing Economy. Stanford Law Review Online, 67, 121-129.

U.S. Department of Housing and Urban Development. (2013). Housing Discrimination Against Racial and Ethnic Minorities 2012.

Yinger, J. (1998). Evidence on Discrimination in Consumer Markets. Journal of Economic Perspectives, 12(2), 23-40.

Zhao, B., Ondrich, J., and Yinger, J. (2005). Why Do Real Estate Brokers Continue to Discriminate? Evidence from the 2000 Housing Discrimination Study. Center for Policy Research. Paper 96. 
forthcoming, American Economic Journal: Applied Economics

\section{Figures}

FIGURE 1. SAMPLE TREATMENT

Respond to Laurie by replying directly to this email.

\section{Q airbnb}

Laurie has sent you an inquiry about Cozy, clean house near Boston. Reply, preapprove or decline by 8:44 AM EDT on Jul 26. Based on your rate of $\$ 100$ per night along with associated fees, your potential payout for this reservation is $\$ 149$.

\section{Pre-approve / Decline}

Reply

$\mathrm{Hi}$, how are you? I am interested in renting your place for a weekend: from 9/20 (Friday at night) through $9 / 22$ (Sunday afternoon). Is there availability? Thank you! -Laurie Ryan

Airbnb Tip: Read our guide for keeping your Airbnb account secure.

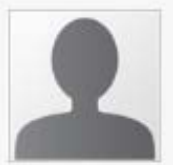

Laurie

4 Verifications 
forthcoming, American Economic Journal: Applied Economics

FIGURE 2. HOST RESPONSES By RACE

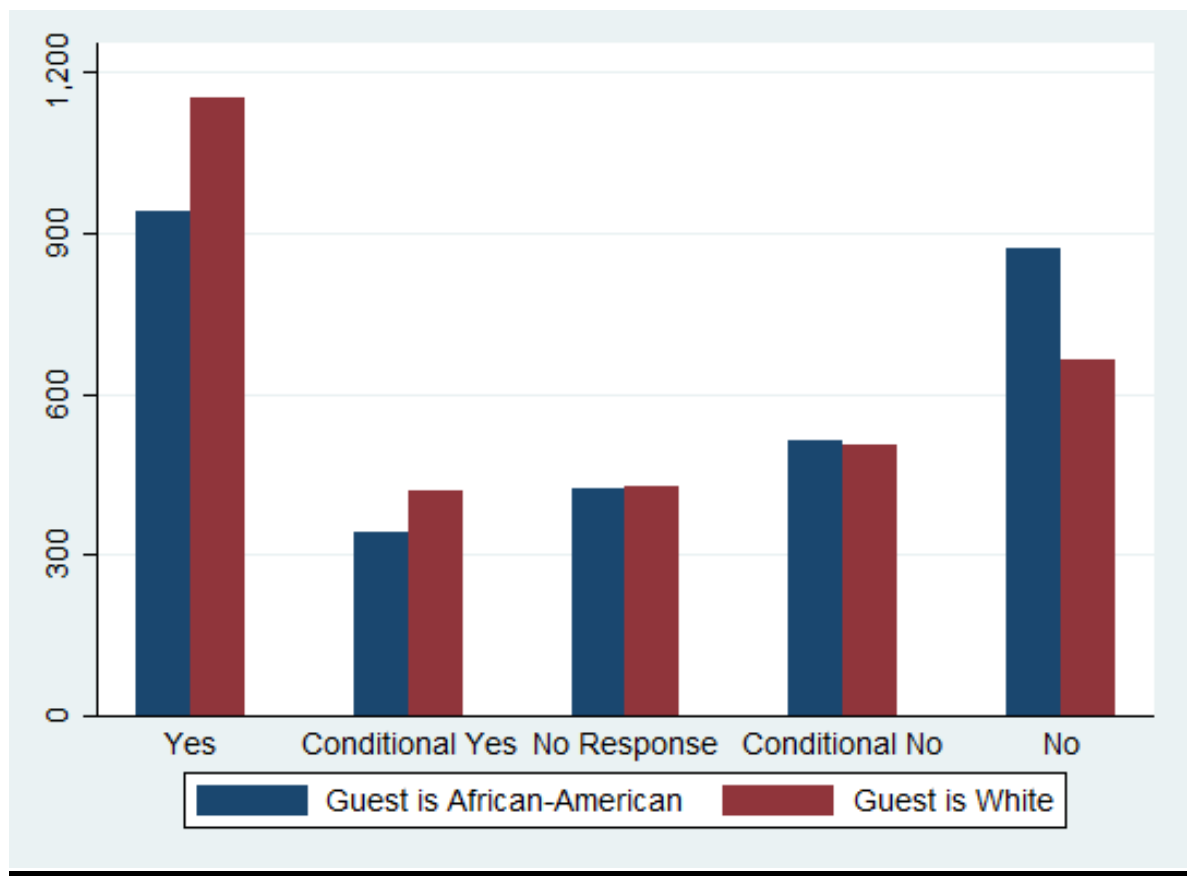


forthcoming, American Economic Journal: Applied Economics

TABLE 1. SUMMARY STATISTICS

\begin{tabular}{|c|c|c|c|c|c|c|c|c|}
\hline Variables & Mean & $\begin{array}{l}\text { Std. } \\
\text { Dev. }\end{array}$ & $\begin{array}{l}\text { 25th } \\
\text { \%ile }\end{array}$ & $\begin{array}{l}\text { 75th } \\
\text { \%ile }\end{array}$ & Obs. & $\begin{array}{l}\text { Mean, } \\
\text { White } \\
\text { Accounts }\end{array}$ & $\begin{array}{c}\text { Mean, } \\
\text { African- } \\
\text { American } \\
\text { Accounts }\end{array}$ & $\begin{array}{c}\mathrm{p}- \\
\text { value }\end{array}$ \\
\hline Host is White & 0.63 & 0.48 & 0 & 1 & 6,392 & 0.64 & 0.63 & 0.15 \\
\hline Host is African-American & 0.08 & 0.27 & 0 & 0 & 6,392 & 0.08 & 0.08 & 0.97 \\
\hline Host is female & 0.38 & 0.48 & 0 & 1 & 6,392 & 0.38 & 0.37 & 0.44 \\
\hline Host is male & 0.30 & 0.46 & 0 & 1 & 6,392 & 0.3 & 0.3 & 0.90 \\
\hline Price (\$) & 181.11 & $1,280.23$ & 75 & 175 & 6,302 & 166.43 & 195.81 & 0.36 \\
\hline Number of bedrooms & 3.18 & 2.26 & 2 & 4 & 6,242 & 3.18 & 3.18 & 0.96 \\
\hline Number of bathrooms & 3.17 & 2.26 & 2 & 4 & 6,285 & 3.17 & 3.17 & 0.93 \\
\hline Number of reviews & 30.87 & 72.51 & 2 & 29 & 6,390 & 30.71 & 31.03 & 0.86 \\
\hline Host has multiple listings & 0.16 & 0.36 & 0 & 0 & 6,392 & 0.32 & 0.33 & 0.45 \\
\hline $\begin{array}{l}\text { Host has } 1+\text { reviews from } \\
\text { African-American guests } \\
\text { Airbnb listings per }\end{array}$ & 0.29 & 0.45 & 0 & 1 & 6,390 & 0.29 & 0.28 & 0.38 \\
\hline $\begin{array}{c}\text { Census tract } \\
\text { \% population African- }\end{array}$ & 9.51 & 9.28 & 2 & 14 & 6,392 & 9.49 & 9.54 & 0.85 \\
\hline American (Census tract) & 0.14 & 0.2 & 0.03 & 0.14 & 6,378 & 0.14 & 0.14 & 0.92 \\
\hline
\end{tabular}


forthcoming, American Economic Journal: Applied Economics

TABLE 2. THE IMPACT OF RACE ON LIKELIHOOD OF ACCEPTANCE

\begin{tabular}{|c|c|c|c|}
\hline & \multicolumn{3}{|c|}{ Dependent Variable: 1(Host Accepts) } \\
\hline Guest is African-American & $\begin{array}{l}-0.08 \\
(0.02)\end{array}$ & $\begin{array}{l}-0.08 \\
(0.02)\end{array}$ & $\begin{array}{l}-0.09 \\
(0.02)\end{array}$ \\
\hline Host is African-American & & $\begin{array}{c}0.07 \\
(0.02)\end{array}$ & $\begin{array}{c}0.09 \\
(0.02)\end{array}$ \\
\hline Host is Male & & $\begin{array}{l}-0.05 \\
(0.01)\end{array}$ & $\begin{array}{l}-0.05 \\
(0.01)\end{array}$ \\
\hline Host has Multiple Listings & & & $\begin{array}{c}0.09 \\
(0.02)\end{array}$ \\
\hline Shared Property & & & $\begin{array}{l}-0.07 \\
(0.02)\end{array}$ \\
\hline Host has $10+$ Reviews & & & $\begin{array}{c}0.12 \\
(0.01)\end{array}$ \\
\hline $\ln$ (Price) & & & $\begin{array}{l}-0.06 \\
(0.01)\end{array}$ \\
\hline Constant & $\begin{array}{c}0.49 \\
(0.01)\end{array}$ & $\begin{array}{c}0.50 \\
(0.01)\end{array}$ & $\begin{array}{c}0.76 \\
(0.07)\end{array}$ \\
\hline $\begin{array}{l}\text { Observations } \\
\text { Adjusted } R^{2}\end{array}$ & $\begin{array}{l}6,235 \\
0.006\end{array}$ & $\begin{array}{l}6,235 \\
0.009 \\
\end{array}$ & $\begin{array}{l}6,168 \\
0.040\end{array}$ \\
\hline
\end{tabular}

Notes: This table reports coefficients from a regression of a "Yes" response on the guest's race and various host and location characteristics. Standard errors are clustered by (guest name)*(city) and are reported in parentheses. 
forthcoming, American Economic Journal: Applied Economics

TABLE 3: Race Gap By Race OF THE Host

\begin{tabular}{|c|c|c|c|c|}
\hline & \multicolumn{4}{|c|}{ Dependent Variable: 1(Host Accepts) } \\
\hline & All Hosts & Male Hosts & Female Hosts & Other Hosts \\
\hline Guest is African-American & $\begin{array}{l}-0.08 \\
(0.02)\end{array}$ & $\begin{array}{l}-0.09 \\
(0.02)\end{array}$ & $\begin{array}{l}-0.09 \\
(0.02)\end{array}$ & $\begin{array}{l}-0.07 \\
(0.03)\end{array}$ \\
\hline Host is African-American & $\begin{array}{c}0.06 \\
(0.03)\end{array}$ & $\begin{array}{c}0.19 \\
(0.05)\end{array}$ & $\begin{array}{l}-0.00 \\
(0.04)\end{array}$ & $\begin{array}{c}0.03 \\
(0.09)\end{array}$ \\
\hline $\begin{array}{l}\text { Host is African-American * } \\
\text { Guest is African-American }\end{array}$ & $\begin{array}{c}0.01 \\
(0.05)\end{array}$ & $\begin{array}{l}-0.11 \\
(0.08)\end{array}$ & $\begin{array}{c}0.11 \\
(0.06)\end{array}$ & $\begin{array}{l}-0.06 \\
(0.14)\end{array}$ \\
\hline Constant & $\begin{array}{c}0.48 \\
(0.01)\end{array}$ & $\begin{array}{c}0.44 \\
(0.02)\end{array}$ & $\begin{array}{c}0.50 \\
(0.02)\end{array}$ & $\begin{array}{c}0.50 \\
(0.02)\end{array}$ \\
\hline Observations & 6235 & 1854 & 2336 & 2045 \\
\hline Adjusted $R^{2}$ & 0.007 & 0.015 & 0.007 & 0.003 \\
\hline $\begin{array}{l}\text { Implied Coefficient on } \\
\text { Guest is African-American } \\
\text { + Host is African-American } \\
\text { * Guest is African-American }\end{array}$ & $\begin{array}{l}-0.07 \\
(0.05)\end{array}$ & $\begin{array}{l}-0.19 \\
(.08)\end{array}$ & $\begin{array}{l}0.02 \\
(.06)\end{array}$ & $\begin{array}{l}-0.12 \\
(0.14)\end{array}$ \\
\hline $\begin{array}{l}\text { Notes: This table reports coeffi } \\
\text { and the interaction between the } \\
\text { host pictures we could not cla } \\
\text { gender couple, } 603 \text { had a pictu } \\
\text { clustered by (guest name)*(city }\end{array}$ & $\begin{array}{l}\text { Other hos } \\
\text { for gendel } \\
\text { thout a hul } \\
\text { are report }\end{array}$ & $\begin{array}{l}\text { on of a "Y } \\
\text { hosts we cc } \\
\text { had a pictl } \\
\text { it, and the } \\
\text { arentheses }\end{array}$ & $\begin{array}{l}\text { onse on the } \\
\text { classify as } \mathrm{m} \\
\text { mixed-gende } \\
\text { ld not be cla }\end{array}$ & $\begin{array}{l}\text { ne, the host's } \\
\text { male. Of the } \\
259 \text { had a s } \\
\text { tandard errol }\end{array}$ \\
\hline
\end{tabular}


forthcoming, American Economic Journal: Applied Economics

TABLe 4. PROPORTION OF Positive Responses by Race AND GENDER

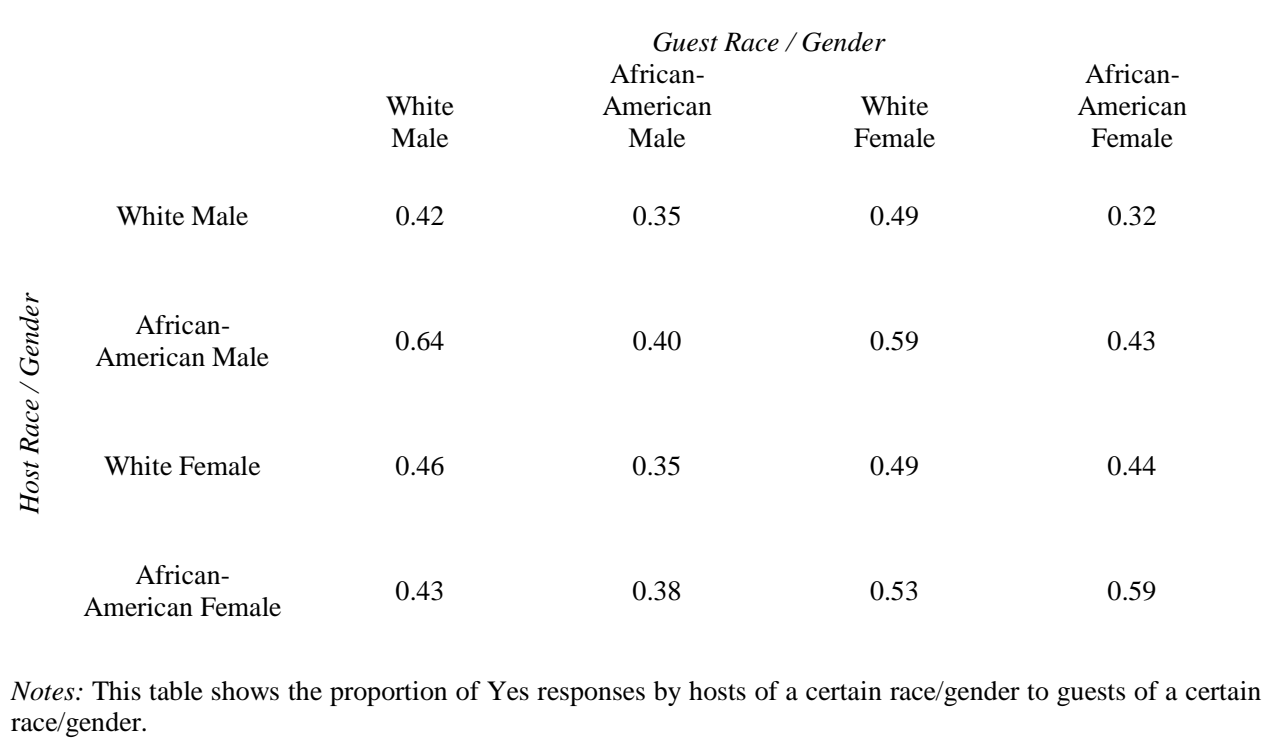


forthcoming, American Economic Journal: Applied Economics

TABLE 5. ARE EFFECTS DRIVEN BY HOST CHARACTERISTICS?

\begin{tabular}{|c|c|c|c|c|c|}
\hline & \multicolumn{5}{|c|}{ Dependent Variable: 1(Host Accepts) } \\
\hline Guest is African-American & $\begin{array}{l}-0.07 \\
(0.02)\end{array}$ & $\begin{array}{l}-0.08 \\
(0.02)\end{array}$ & $\begin{array}{l}-0.09 \\
(0.02)\end{array}$ & $\begin{array}{l}-0.11 \\
(0.02)\end{array}$ & $\begin{array}{l}-0.09 \\
(0.02)\end{array}$ \\
\hline Shared Property & $\begin{array}{c}0.00 \\
(0.01)\end{array}$ & & & & \\
\hline Shared Property * Guest is African-American & $\begin{array}{l}-0.02 \\
(0.03)\end{array}$ & & & & \\
\hline Host has Multiple Listings & & $\begin{array}{c}0.14 \\
(0.02)\end{array}$ & & & \\
\hline $\begin{array}{c}\text { Host has Multiple Listings * Guest is African- } \\
\text { American }\end{array}$ & & $\begin{array}{l}-0.01 \\
(0.03)\end{array}$ & & & \\
\hline Host has $10+$ Reviews & & & $\begin{array}{c}0.14 \\
(0.02)\end{array}$ & & \\
\hline $\begin{array}{c}\text { Host has Ten+ Reviews * Guest is African- } \\
\text { American }\end{array}$ & & & $\begin{array}{c}0.01 \\
(0.02)\end{array}$ & & \\
\hline Host Looks Young & & & & $\begin{array}{l}-0.03 \\
(0.02)\end{array}$ & \\
\hline $\begin{array}{l}\text { Host Looks Young * Guest is African- } \\
\text { American }\end{array}$ & & & & $\begin{array}{l}-0.01 \\
(0.02)\end{array}$ & \\
\hline $\begin{array}{l}\text { Host has } 1+\text { reviews from an African- } \\
\text { American guest }\end{array}$ & & & & & $\begin{array}{c}0.10 \\
(0.01)\end{array}$ \\
\hline $\begin{array}{l}\text { Host has } 1+\text { reviews from an African- } \\
\text { American guest } * \text { Guest is African-American }\end{array}$ & & & & & $\begin{array}{c}0.06 \\
(0.02)\end{array}$ \\
\hline Constant & $\begin{array}{c}0.49 \\
(0.01)\end{array}$ & $\begin{array}{c}0.46 \\
(0.01)\end{array}$ & $\begin{array}{c}0.42 \\
(0.01)\end{array}$ & $\begin{array}{c}0.50 \\
(0.01)\end{array}$ & $\begin{array}{c}0.46 \\
(0.01)\end{array}$ \\
\hline $\begin{array}{l}\text { Observations } \\
\text { Adjusted } R^{2}\end{array}$ & $\begin{array}{l}6,235 \\
0.006\end{array}$ & $\begin{array}{l}6,235 \\
0.014\end{array}$ & $\begin{array}{l}6,235 \\
0.027\end{array}$ & $\begin{array}{l}6,235 \\
0.011\end{array}$ & $\begin{array}{l}6,235 \\
0.019\end{array}$ \\
\hline $\begin{array}{c}\text { Implied Coefficient on Guest is African- } \\
\text { American + Host Trait * Guest is African- } \\
\text { American }\end{array}$ & $\begin{array}{l}-0.09 \\
(0.02)\end{array}$ & $\begin{array}{l}-0.09 \\
(0.03)\end{array}$ & $\begin{array}{l}-0.08 \\
(0.02)\end{array}$ & $\begin{array}{l}-0.08 \\
(0.03)\end{array}$ & $\begin{array}{c}-0.04 \\
(0.03)\end{array}$ \\
\hline
\end{tabular}

Notes: This table reports coefficients from a regression of a "Yes" response on the guest's race, various host characteristics, and the interaction between the two. Standard errors are clustered by (guest name)*(city) and are reported in parentheses. 
forthcoming, American Economic Journal: Applied Economics

TABLE 6. ARE EFFECTS DRIVEN BY LOCATION CHARACTERISTICS?

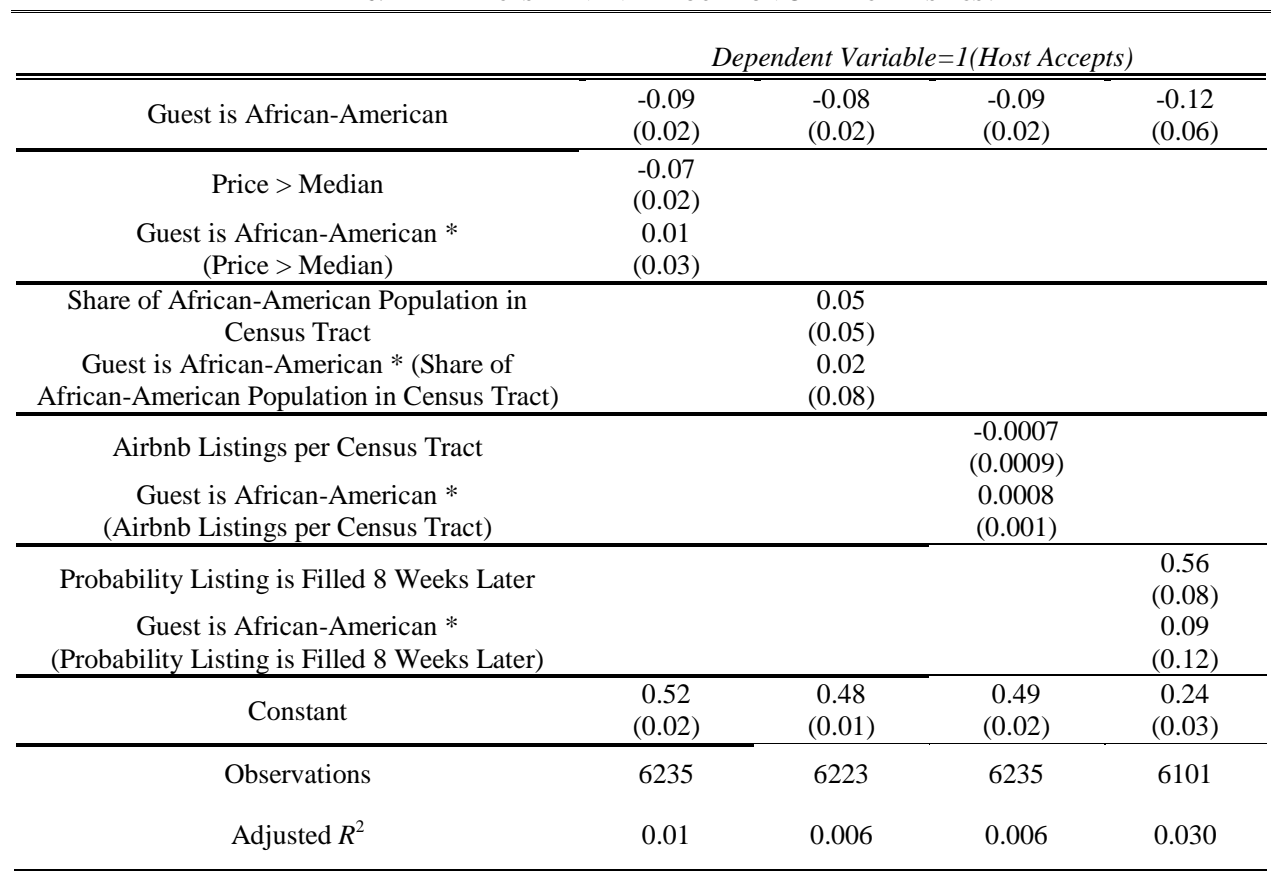

Notes: This table reports coefficients from a regression of a "Yes" response on the guest's race, various location characteristics, and the interaction between the two. Standard errors are clustered by (guest name)*(city) and are reported in parentheses. 
forthcoming, American Economic Journal: Applied Economics

TABLE 7. PROPORTION OF Positive Responses, By NAME

\begin{tabular}{|c|c|c|c|}
\hline \multicolumn{2}{|c|}{ Entire Sample } & \multicolumn{2}{|c|}{$\begin{array}{c}0.43 \\
(6,390)\end{array}$} \\
\hline \multicolumn{2}{|c|}{ White Female } & \multicolumn{2}{|c|}{ African-American Female } \\
\hline Allison Sullivan & $\begin{array}{c}0.49 \\
(306)\end{array}$ & Lakisha Jones & $\begin{array}{c}0.42 \\
(324)\end{array}$ \\
\hline Anne Murphy & $\begin{array}{c}0.56 \\
(344)\end{array}$ & Latonya Robinson & $\begin{array}{c}0.35 \\
(331)\end{array}$ \\
\hline Kristen Sullivan & $\begin{array}{c}0.48 \\
(325)\end{array}$ & Latoya Williams & $\begin{array}{c}0.43 \\
(327)\end{array}$ \\
\hline Laurie Ryan & $\begin{array}{c}0.50 \\
(327)\end{array}$ & Tamika Williams & $\begin{array}{c}0.47 \\
(339)\end{array}$ \\
\hline Meredith O’Brien & $\begin{array}{c}0.49 \\
(303)\end{array}$ & Tanisha Jackson & $\begin{array}{l}0.40 \\
(309)\end{array}$ \\
\hline \multicolumn{2}{|c|}{ White Male } & \multicolumn{2}{|c|}{ African-American Male } \\
\hline Brad Walsh & $\begin{array}{c}0.41 \\
(317)\end{array}$ & Darnell Jackson & $\begin{array}{c}0.38 \\
(285)\end{array}$ \\
\hline Brent Baker & $\begin{array}{c}0.48 \\
(332)\end{array}$ & Jamal Jones & $\begin{array}{c}0.33 \\
(328)\end{array}$ \\
\hline Brett Walsh & $\begin{array}{c}0.44 \\
(279)\end{array}$ & Jermaine Jones & $\begin{array}{c}0.36 \\
(300)\end{array}$ \\
\hline Greg O’Brien & $\begin{array}{c}0.45 \\
(312)\end{array}$ & Rasheed Jackson & $\begin{array}{c}0.38 \\
(313)\end{array}$ \\
\hline Todd McCarthy & $\begin{array}{c}0.43 \\
(314)\end{array}$ & Tyrone Robinson & $\begin{array}{c}0.36 \\
(254)\end{array}$ \\
\hline
\end{tabular}

Notes: The table reports the proportion of Yes responses by name. The number of messages sent by each guest name is shown in parentheses. 
forthcoming, American Economic Journal: Applied Economics

\section{Appendix}

APPENDIX TABLE 1: RESULTS OF SURVEY TESTING RACES ASSOCIATED WITH NAMES

\begin{tabular}{lccc}
\multicolumn{2}{c}{ APPENDIX TABLE 1: RESULTS OF SURVEY TESTING RACES ASSOCIATED WITH NAMES } \\
\hline \multicolumn{1}{c}{ White Female } & \multicolumn{2}{c}{ African-American Female } \\
$\begin{array}{l}\text { Meredith O’Brien } \\
\text { Anne Murphy }\end{array}$ & 0.93 & Tanisha Jackson & 0.03 \\
Laurie Ryan & 0.95 & Lakisha Jones & 0.05 \\
Allison Sullivan & 0.98 & Latoya Williams & 0.05 \\
Kristen Sullivan & 1.00 & Latonya Robinson & 0.07 \\
White Male & & Tamika Williams & 0.07 \\
Greg O‘Brien & 0.88 & African-American Male \\
Brent Baker & 0.90 & Tyrone Robinson & 0.00 \\
Brad Walsh & 0.91 & Rasheed Jackson & 0.06 \\
Brett Walsh & 0.93 & Jamal Jones & 0.07 \\
Todd McCarthy & 0.98 & Darnell Jackson & 0.10 \\
& & Jermaine Jones & 0.26
\end{tabular}

Notes: "White" is coded as 1. "African-American" is coded as 0. Sample size $=62$. 


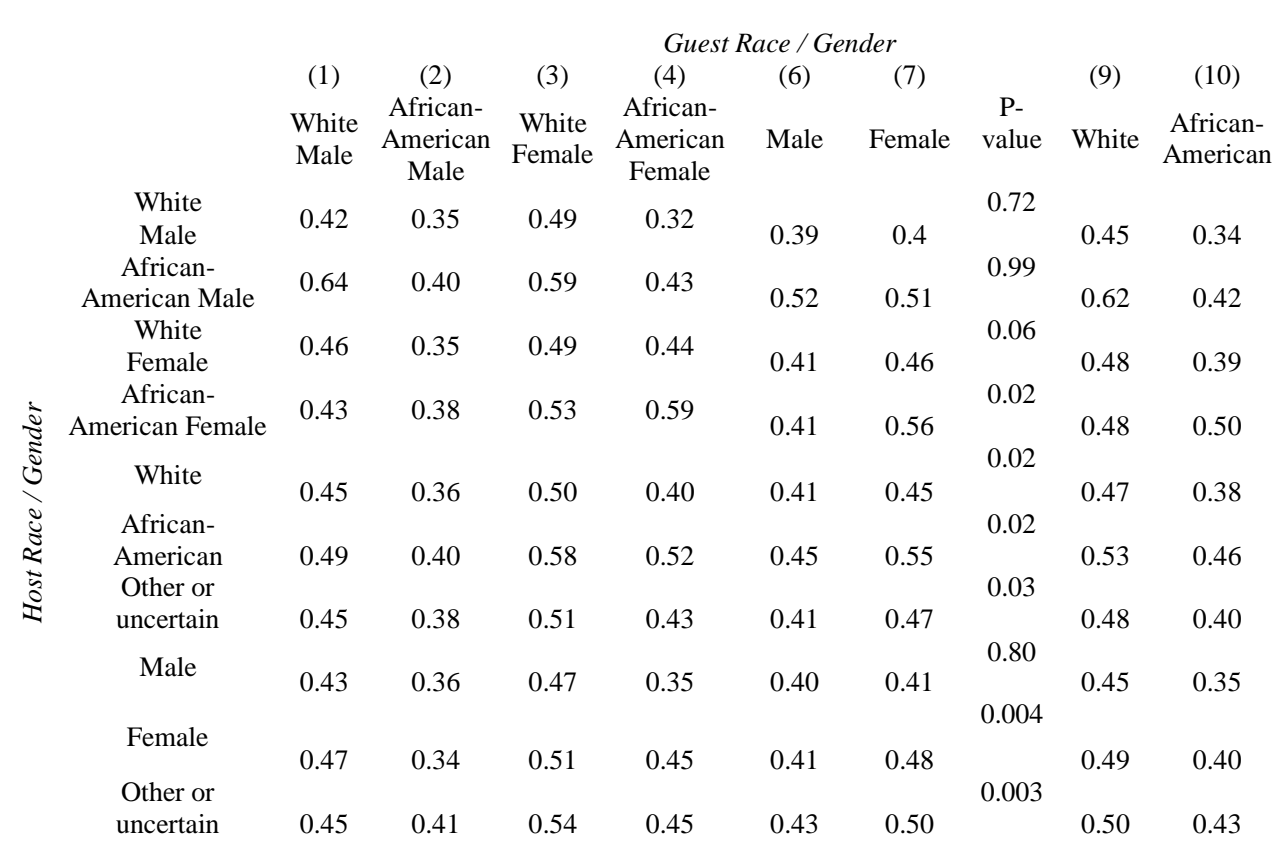

Notes: This table shows the proportion of Yes responses by hosts of a certain race/gender to guests of a certain race/gender. 
forthcoming, American Economic Journal: Applied Economics

APPENDIX TABLE 3: DISCRIMINATION BY CITY

\begin{tabular}{|c|c|c|c|c|c|c|}
\hline \multicolumn{7}{|c|}{ Dependent Variable: 1(Host Accepts) } \\
\hline & $\begin{array}{c}\text { All } \\
\text { Cities }\end{array}$ & $\begin{array}{l}\text { Baltimore } \\
(\mathrm{N}=347)\end{array}$ & $\begin{array}{c}\text { Dallas } \\
(\mathrm{N}= \\
415)\end{array}$ & $\begin{array}{c}\text { Los } \\
\text { Angeles } \\
(\mathrm{N}=3,913)\end{array}$ & $\begin{array}{l}\text { St. Louis } \\
(\mathrm{N}=151)\end{array}$ & $\begin{array}{c}\text { Washington, } \\
\text { D.C. } \\
(\mathrm{N}=1,559)\end{array}$ \\
\hline $\begin{array}{c}\text { Guest is African- } \\
\text { American }\end{array}$ & -0.08 & $\begin{array}{l}-0.07 \\
(0.02)\end{array}$ & $\begin{array}{l}-0.08 \\
(0.02)\end{array}$ & $\begin{array}{l}-0.10 \\
(0.02)\end{array}$ & $\begin{array}{l}-0.08 \\
(0.03)\end{array}$ & $\begin{array}{l}-0.08 \\
(0.02)\end{array}$ \\
\hline City & -- & $\begin{array}{c}0.07 \\
(0.03)\end{array}$ & $\begin{array}{c}0.04 \\
(0.03)\end{array}$ & $\begin{array}{l}-0.00 \\
(0.03)\end{array}$ & $\begin{array}{c}0.02 \\
(0.05)\end{array}$ & $\begin{array}{l}-0.03 \\
(0.04)\end{array}$ \\
\hline $\begin{array}{l}\text { City * Guest is } \\
\text { African-American }\end{array}$ & -- & $\begin{array}{l}-0.12 \\
(0.05)\end{array}$ & $\begin{array}{l}-0.01 \\
(0.04)\end{array}$ & $\begin{array}{c}0.03 \\
(0.04)\end{array}$ & $\begin{array}{c}0.02 \\
(0.07)\end{array}$ & $\begin{array}{l}-0.01 \\
(0.05)\end{array}$ \\
\hline Constant & 0.49 & $\begin{array}{c}0.48 \\
(0.01)\end{array}$ & $\begin{array}{c}0.49 \\
(0.01)\end{array}$ & $\begin{array}{c}0.49 \\
(0.02)\end{array}$ & $\begin{array}{c}0.49 \\
(0.01)\end{array}$ & $\begin{array}{c}0.50 \\
(0.01)\end{array}$ \\
\hline Observations & 6,235 & 6,235 & 6,235 & 6,235 & 6,235 & 6,235 \\
\hline Adjusted $\mathrm{R}^{2}$ & 0.006 & 0.007 & 0.006 & 0.006 & 0.006 & 0.007 \\
\hline $\begin{array}{c}\text { Implied Coefficient } \\
\text { on Guest is African- } \\
\text { American + City * } \\
\text { Guest is African- } \\
\text { American }\end{array}$ & -- & $\begin{array}{l}-0.19 \\
(0.04)\end{array}$ & $\begin{array}{l}-0.09 \\
(0.04)\end{array}$ & $\begin{array}{l}-0.07 \\
(0.02)\end{array}$ & $\begin{array}{l}-0.06 \\
(0.06)\end{array}$ & $\begin{array}{l}-0.09 \\
(0.05)\end{array}$ \\
\hline
\end{tabular}

Notes: This table reports coefficients from a regression of a "Yes" response on the guest's race, a city, and the interaction of city and guest race. Standard errors are clustered by (guest name)*(city) and are reported in parentheses. 
forthcoming, American Economic Journal: Applied Economics

APPENDIX TABLE 4: HOST RESPONSES TO GUEST INQUIRIES, BY RACE OF THE GUEST

\begin{tabular}{|c|c|c|}
\hline & White Guests & $\begin{array}{c}\text { African-American } \\
\text { Guests }\end{array}$ \\
\hline Yes & 1,152 & 940 \\
\hline Yes, but request for more information & 375 & 308 \\
\hline Yes, with lower price if booked now & 11 & 10 \\
\hline Yes, if guest extends stay & 10 & 15 \\
\hline Yes, but in a different property & 18 & 8 \\
\hline Yes, at a higher price & 4 & 0 \\
\hline Request for more information & 339 & 323 \\
\hline Not sure or check back later & 154 & 175 \\
\hline No response & 429 & 423 \\
\hline No unless more information is provided & 12 & 15 \\
\hline No & 663 & 873 \\
\hline
\end{tabular}

